\begin{tabular}{l|l} 
Variants & $\begin{array}{l}\text { Variants } \\
\text { The Journal of the European Society for Textual } \\
\text { Scholarship }\end{array}$
\end{tabular}

$12-13$ | 2016

Varia

\title{
Genetic Criticism Put to the Test by Digital Technology: Sounding out the (mainly) Digital Genetic File of El Dorado by Robert Juan-Cantavella
}

\section{Bénédicte Vauthier}

\section{(2) OpenEdition}

\section{Journals}

Electronic version

URL: http://journals.openedition.org/variants/353

DOI: 10.4000/variants.353

ISSN: 1879-6095

\section{Publisher}

European Society for Textual Scholarship

\section{Printed version}

Date of publication: 31 December 2016

Number of pages: 163-186

ISSN: 1573-3084

\section{Electronic reference}

Bénédicte Vauthier, «Genetic Criticism Put to the Test by Digital Technology: Sounding out the

(mainly) Digital Genetic File of El Dorado by Robert Juan-Cantavella », Variants [Online], 12-13 | 2016,

Online since 01 May 2017, connection on 01 May 2019. URL : http://journals.openedition.org/ variants/353; DOI : 10.4000/variants.353 


\section{Genetic Criticism Put to the Test by Digital Technology}

\section{Sounding out the (mainly) Digital Genetic File of $E l$ Dorado by Robert Juan-Cantavella}

Bénédicte Vauthier

To Jean-Louis Lebrave, for his unequalled lessons in the subject

Abstract: The opportunity to analyse the digital files used in the composition of Robert Juan-Cantavella's El Dorado (2008), the Spanish propagator of Gonzo Journalism, presents a fascinating test case to test the limits and opportunities of genetic criticism. Far from showing that the age of the computer ends all access to the genetic material, this study carefully lays out the wealth of material available to manuscript students. The data preserved on the author's USB stick - file structures, file names, date stamps, etc. — and the relation between these proves to be crucial to the reconstruction of the genetic sequence, the writing methods, and an understanding of the creation of Juan-Cantavella's poetics of fictionalizing reality. Keywords: authorship; digital archive; composition history; genetic criticism; methodology; Spanish literature; Robert Juan-Cantavella.

L'URGENCE SERAIT plutôt de mobiliser les énergies pour aborder deux questions cruciales pour l'avenir de la critique génétique. Pour la première, il s'agit de savoir vraiment comment les écrivains s'approprient l'ordinateur, et quels sont les effets de cette appropriation sur l'écriture. Quant à la seconde, elle concerne la manière dont nous généticiens serons capables de construire de véritables objets scientifiques à partir des données d'un nouveau type stockées dans la mémoire des ordinateurs. (Lebrave 2010, 155)

[It would be a much greater matter of urgency to mobilize the energy for approaching two crucial questions for the future of genetic criticism. First, it is about really knowing how the writers appropriate the computer, and which are the effects of this appropriation on 
writing. The second concerns the way in which geneticists will be able to construct real scientific objects based on data of a new type stored on computer memories.']

This twofold diagnosis - realistic and final - is nothing less than the friendly "post-scriptum" of an open letter jointly sent by Louis Hay and Jean-Louis Lebrave (master and disciple, pioneers in French genetic criticism) to Pierre-Marc de Biasi (at the time director of the Institut des Textes et Manuscrits Modernes) in reply to a eulogistic and too optimistic article titled "Pour une génétique généralisée: l'approche des processus à l'âge numérique" (2010). It was published in an issue of Genesis which, after a two year hiatus, drew up a status quaestionis of the theory of genetic criticism. De Biasi advocated the use of digital technology: the digital permits to solve quantitative problems of huge volumes unpublishable on paper. It adds the logical and dynamic capacities of a medium that, thanks to the hypertext, allows to go beyond the sequential character of the page and the book.

In the digital era, these two fields are, of course, not the only ones to witness the revolution that has taken place in the Humanities since the 1980s. As the initial quotation by Lebrave clearly indicates, the hubs of creation on the one hand and of criticism and interpretation on the other, have equally been affected with full force by these changes. The position defended by de Biasi is somewhat surprising. In fact, ignoring the generalized pessimism among critics, especially the geneticists or the philologists (see Ries 2010, 151-52), de Biasi considers the apocalyptic fears of the doomsayers who had declared: "Plus de manuscrits, plus de brouillons? C'est donc la fin de la génétique!" (de Biasi 2010, 171) ("No more manuscripts, no more rough drafts? It is thus the end of genetics!") unfounded and futile. For him, "c'est même le contraire. L'ordinateur conserve spontanément la trace de toutes les commandes que vous lui avez adressées, toutes intégralement, d'un bout à l'autre de chaque session de travail, aussi longtemps que vous ne procéderez pas à un écrasement délibéré de sa mémoire" ("the opposite is the case. The computer spontaneously keeps track of all commands given from start to finish of each work session, as long as you do not proceed to deliberately overwrite its memory") 
(de Biasi 2010, 171). Thus, against all odds, the computer proves to be the geneticist's best ally.

From the outset, we ought to note, however, that his enthusiasm for the computer ignores the (human and technological) difficulties that come with the adopting digital tools and methods (from the analysis and establishment of a model to the visualization and publication by way of transcription and encoding, for example in TEI). What the study of digital genetic files is concerned, it simply disregards the competencies in computer technology with which the philologist or geneticist of the twenty-first century certainly has to equip himself. ${ }^{1}$

The issue is underlined in another article by Lebrave in which he echoed studies in English and German regarding "les méthodes et outils de l'informatique légale appliquée à l'écriture numérique" ("the legal information technology methods and tools applied to digital writing") $(2011,137)$, especially those by the scholar of German studies, Thorsten Ries (2010). Ries seeks to lay the foundations of a "philologie numérique des sources" ("digital philology of sources") (Lebrave 2011, 137) based on the joint contributions of computer forensics and French genetic criticism. Lebrave knows what he is talking about. He is a pioneer in genetic criticism, and also in "génétique électronique" ("electronic genetics"): he was among the first to participate in the creation of tools to be used with electronic corpora (Philectre, EDITE, MEDITE, etc.) (Lebrave 2008 and 2012). In these highly instructive early articles he has shown how the computer is not simply an "outil d'aide à la recherche" ("support tool for research"), but is instead an unparalleled "outil éditorial" ("editorial tool") which allows not only for the online release of voluminous genetic files, but also for the interactive use of these files (Lebrave 1994, 2009). Finally, he shows the route that the geneticists could take by drawing attention to the encouraging results stemming from Ries' analysis of the experimental corpus of Michael Speier's poem ausfahrt st. nazaire (Ries 2010) and coins the neologism génétique inforensique to denote this type of investigation. ${ }^{2}$ The benefits notwithstanding, he is aware that there are

1 See, for example, the technical documentation and the preliminaries which accompany the digital Beckett or Juan Goytisolo projects (see http:// www.beckettarchive.org and http://www.goytisolo.unibe.ch).

2 Ries has extended the study of literary genesis following Kirschenbaum's 
significant challenges as well. The use of the computer in literary studies requires "des "compétences très étendues" ("wide-ranging expertise") in a "branche hautement spécialisée de l'informatique" ("highly specialized field of informatics") (Lebrave 2011, 146); such expertise may well be beyond the means of the individual researcher, and available only to collaborative, externally funded collaborative projects.

My presuppositions and conclusions are generally in accordance with those of Thorsten Ries (2010): critical genetics has not lost its function, but it urgently needs to develop a technique for tackling digital media. However, I deliberately apply myself to a more modest challenge than Ries's: to analyse the (for the most part) digital genetic dossier of Robert Juan-Cantavella's third novel, El Dorado (2008). A more modest challenge, indeed, because it has never been a question for me to resort to the author's hard disk, nor to try transposing the methods or tools of legal information technology to a genetic study, as Ries has successfully done. I do not have the requisite, nor do intend to acquire them.

It cannot be denied - and this is the main difficulty - that word processing flattens out, even crushes the two-dimensionality of the page, and thereby hides the abundant writing operations which manuscripts genetics seeks to unravel. Moreover, the concealment of basic data with which the geneticist is used to working seems to challenge the creation and reading process of the genetic file, the main stages of which are summarized by Almuth Grésillon in Éléments de critique génétique. In fact, does anything remain of the conception developed by the French school of genetic criticism whose objective was to study "les manuscrits de travail des écrivains en tant que support matériel, espace d'inscription et lieu de mémoire des œuvres in statu nascendi" ("the writers' drafts insofar as it is material object, inscription space and memory place of the work in statu nascendi") (Grésillon 1994, 1)? What can the genetic critic do in terms of positioning, dating, classification operations and particularly the decoding of a digital draft? Despite the disappearance of the traces of inscription, there is more to digital genetic criticism than just that. Something else happens entirely when the researcher receives a USB stick out of the author's hands or an

proposals regarding the intersection between material bibliography, digital archiving and critical edition (see Kirschenbaum 2008). 
access key to a virtual storage service such as Dropbox. The digital files that she finds there set ajar the door to the twenty-first century writer's studio.

In other words, traces remain, reduced and blurry maybe, but traces nonetheless. "La trace, toute la trace et rien que la trace" ("The trace, the whole trace and nothing but the trace"), this is the founding principle of genetic criticism, as Louis Hay puts it (Hay 2010, 154). Therefore, we can reply to Claire Doquet-Lacoste, who fears that "[l]es traces de la troisième dimension de l'écriture, sa temporalité, [. . .] sont atténuées — voire disparaissent - avec l'ordinateur" (Doquet-Lacoste 2007, 37) ("the traces of the third dimension of writing, its temporality, [. . . ] are attenuated - they even disappear - with the computer"), that the traces do not disappear. On the contrary, they increase in number, but they look different. It may therefore seem that "le traitement de texte semble faire tomber dans l'oubli les essais successifs pour ne conserver de chaque énoncé que sa version la plus récente" $(2007,37)$ ("the treatment of the text seems to make the successive attempts sink into oblivion by solely preserving the most recent version of each utterance"), but the digital dossier offers other means to retrieve those temporalities. As a result, there is no reason for questioning "la pérennité de l'approche génétique, ancrée dans la recherche d'une production singulière" $(2007,39)$ ("the sustainability of the genetic approach, anchored in the research of a singular production") in order to defend again the use of software such as Genèse $d u$ Texte, Scriptlog or Inputlog. If these programs allow us to analyse (real or even film) time in a minute way, they will also suffocate the researcher in the abundance of data.

To overcome these obstacles, geneticists should learn to make use of a systematic collation of superficially similar versions, but different in essence, a method already familiar to philologists, just as Lebrave admits, when he affirms that

à partir du moment où on appréhende les données de la génétique sous forme de données de langue, il est vain de prétendre [.. . à une originalité absolue du matériau génétique. Il n'y a pas de différence radicale entre des états textuels variants et la variation qu'on peut observer dans les brouillons. [. . .] On peut donc réconcilier la philologie et la génétique et unifier le panorama de la variation textuelle. (Lebrave 2009, 18) 
[from the moment one understands the genetic data as a form of language data, it becomes pointless to pretend [...] that the genetic material is absolutely unique. There is no radical difference between the textual variants and the variation that we can observe in the rough drafts. [...] We can, thus, reconcile philology and genetics and unify the overview of textual variation.]

Therefore, it is no surprise that only two years later he admits that "[1]a génétique inforensique risque donc de devoir définitivement renoncer à être une poétique des processus pour se contenter d'être une poétique des transitions entre états" (Lebrave 2011, 145) ("the inforensic genetics thus risks having to give up definitely on being a poetics of processes in order to settle for being a poetics of transitions between stages"). As Lebrave recognizes, the collation could be done with software, e.g. using tools like MEDITE, Juxta, or manually.

In line with the empirical epistemology defended by Louis Hay (1985), the inductive analysis of Robert Juan-Cantavella's genetic file, which I undertook without resorting to any software, unexpectedly turned out to be quite rich in temporal information. In the following section I will continue to explain how I proceeded and which are the results of the search.

\section{Geneticists face the digital challenge}

\section{The genetic file}

Robert Juan-Cantavella, a Spanish writer who belongs to the Nueva narrativa española (Kunz and Gómez, 2014), handed me the "sketches" and "drafts" of El Dorado in Bern on Friday, 18 November 2011. Despite their considerable number they all fitted on a USB stick. They were arranged by the author in four folders named [ED 27 (FINAL)], [ED fotos], [ED materiales], [ED versions anteriors]. Each of these folders contained one or more subfolders, which, in turn, contained other subsubfolders with hundreds of files (text, photo, audio, video, links). All together the files on the stick comprised twentyseven versions of the novel. In the folder [ED materiales], a true hotchpotch of digital writing, we found among other things, the subfolders "on" and "off" — sometimes followed by the title of one of the parts of the novel. The USB drive is thus at the same time 

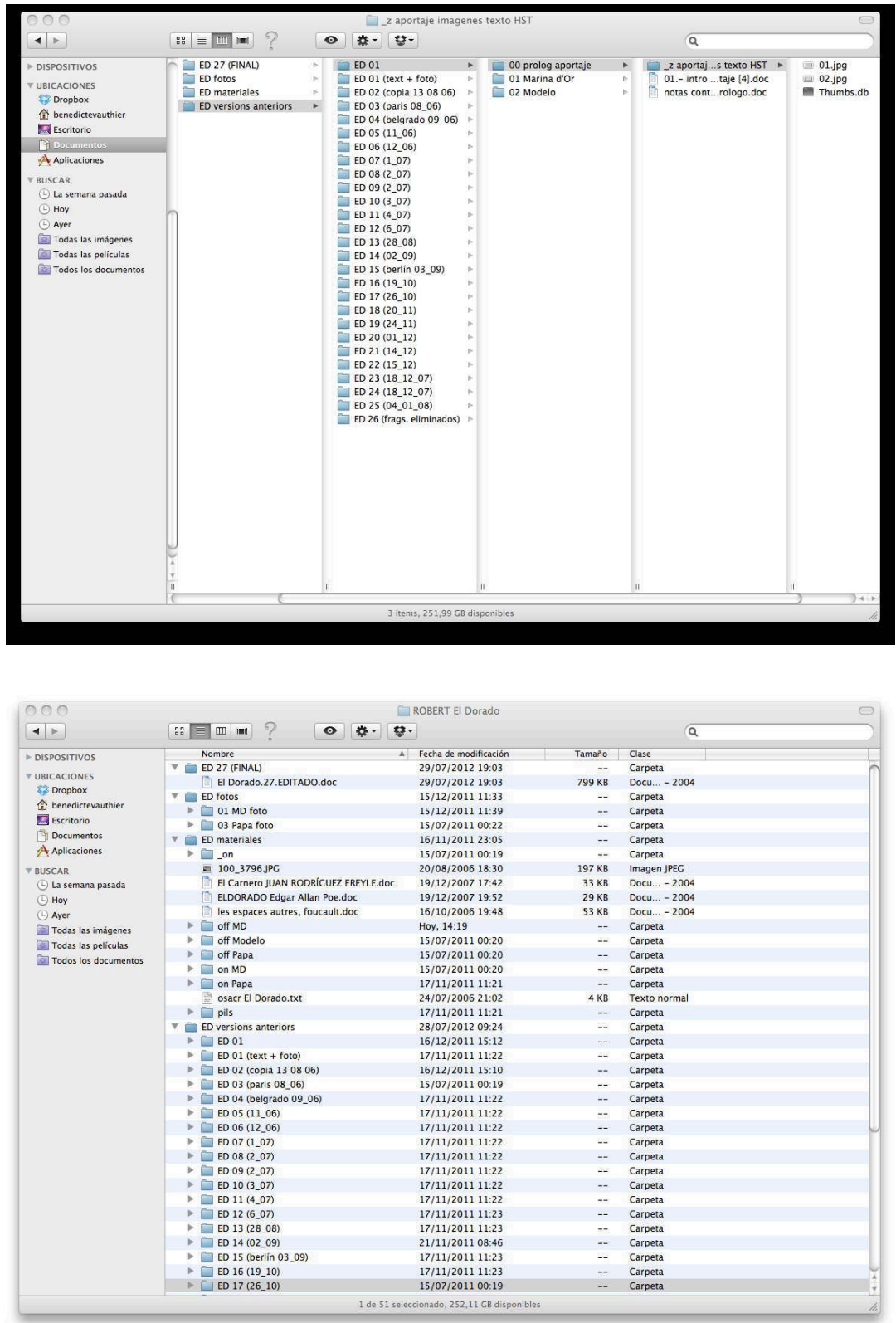

Figures 1 and 2: Screenshots of the tree structure of the digital archives of El Dorado. 
a "virtual library" (on) which preserves a great variety of integrated documents and "virtual bin" (off) in which the rejected material is located. Both folders facilitate access to numerous intermedial and textual sources that the author used in constructing his work. Once they are related to one or other version of the novel, they allow us to see how exogenesis becomes endogenesis (de Biasi, 1998).

This first delivery was followed by another transfer of materials in Paris on 16 December of the same year. This time it was a backpack carrying the logo of the "V encuentro mundial de familias" (" $5^{\text {th }}$ World Meeting of Families") which was held in Valencia in 2006. In this backpack, the author had gathered the extant pre-textual material - some newspapers and magazines, some promotional brochures, a printout of one of the versions of the novel with handwritten corrections, and last but not least a black rubber notebook (measuring $15 \times 9 \mathrm{~cm}$ ) with around a hundred pages of handwritten notes written on both sides. ${ }^{3}$ The survival of this material is sufficient material to refute the cliché that young digital native writers only write on computers. The analysis of the digital folders shows that these notes were quickly, but neatly written out, almost without any rewriting - a fact that is confirmed by the author's autofictional alter ego, Trebor Escargot.

Sigo escribiendo en la libreta, sí señor, tomo notas, ya sabes... el ordenador viene después, cuando llego a la habitación [...] justo allí donde antes me las veía con mi máquina de escribir. En lugar de ordenar mis notas como hacía antes, ahora las transcribo en el ordenador de tal forma que, sin darme demasiada cuenta, voy escribiendo la historia, le doy forma a mi aportaje. Y cuando te digo que las cosas han cambiado lo digo muy en serio, antes, como sabes, yo escribía de forma consecutiva y apasionada, y ahora el tema es diferente, ahora escribo por capas, como hacen los diseñadores con sus programas de tratamiento de imagen... aunque qué voy a contarle a un troglodita como tú ... (Juan-Cantavella 2008, 170)

[I keep writing in the notebook, yeah, I take notes, you know ... the computer comes later, when I get to my room [. . .] just there where before I could be seen writing on a typewriter. Instead of ordering my notes like I did before, now I transcribe them on the computer in a way that without realising, I am writing the story,

3 For a detailed discussion of the material, see Vauthier 2014, 314-31. 
I give form to my unreport. And when I tell you that things have changed I tell you that very seriously, before, as you know, I wrote in a consecutive and passionate way, and now the matter is different, now I write layer-by-layer, as the designers do with their image processing software ... though what am I going to tell a caveman like you...]

As we will see in the second part of this article (II), which focuses on the new modalities of creation, a web page created by the author has to be added to this already hybrid genetic file. The back cover of the published novel refers the reader to this web page to find out more detail about Trebor Escargot's work. ${ }^{4}$

\section{The digital tree structures and a new temporariness}

An attentive study of the constituent tree structure of the twenty seven archived versions of the novel, contained in the files [ED 27 (FINAL)] and [ED versions anteriors], can address many concerns about the process of composition of the work, in particular of the macrostructural changes. In order to understand some of these, I have to specify that El Dorado belongs to the aesthetics of the Punk - or Pulp - Journalism, "a bastard form" $(2008,189)$ or "failed experiment" of Gonzo Journalism or New Journalism. More precisely, El Dorado can be read as a Spanish rereading of Fear and Loathing in Las Vegas: A Savage Journey to the Heart of the American Dream by the American founder of the genre, Hunter S. Thompson, as well as of the movie Las Vegas Parano directed by Terry Gilliam.

Juan-Cantavella's novel consists of four parts that are to varying degrees different from one another. The fourth and last part is the shortest; it consists of only three pages (pp. 345-347) whose story takes places on a single day, 1 May 2007, in Berlin's Kreuzberg. It is in other words set much later than the other parts of the novel (which take place between 1 and 8 July 2006) and in a different locale (Berlin rather than Valencia).

The first part (pp. 17-147), or first gonzo unreport, ${ }^{5}$ consists of four chapters, subdivided, in turn, into several subsections. The

4 See http://www.punkjournalism.net.

5 The term unreport was created by analogy with the Spanish aportaje, which consists of a the negative prefix $a-+$ a clipped form of reportaje (portaje). 
chapters cover the first four days of July ( Saturday the $1^{\text {st }}$ to Tuesday the $4^{\text {th }}$ ) that Trebor Escargot spends alone in Marina d'Or. This is a "paraíso a orillas del Mediterráneo" ("paradise on the shores of the Mediterranean Sea") (p. 17) "para escribir un aportaje sobre la realidad y las cosas que verdaderamente suceden ahí fuera" ("to write an unreport about reality and the things that really happen out there") (p. 26). The reality in which the protagonist immerses himself is particularly difficult to relate because Trebor Escargot knows that, in order to reach it, relying on the body, the observation and drugs - all present in Gonzo Journalism - are not enough; nor does he believe in the Malinowskian anthropological empathy. After Hunter S. Thompson, this is the second intertextual counterpoint in the novel, a decisive counterpoint to understand the structural changes. This first part is archived in the digital files under the initials MD, for Marina d'Or.

The second part, of roughly sixty pages (pp. 151-216), takes place in just one day, Wednesday, 5th July. The protagonist picks up his friend Brona who leaves the "Modelo" prison, which becomes the name of the archives, and is subdivided into three sections: "Película hacia el sur. Sin Bromas" ("Movie towards the south. Without jokes"), "El aportaje y el Punk Journalism" ("The unreport and Punk Journalism") and "Película hacia el sur. Con Brona" ("Movie towards the south. With Brona"), with the second being something like the fictionalized poetics of the novel.

The third part, or second gonzo unreport, of some hundred and twenty pages (pp. 219-342), similar in extent in other words to the first one, takes place in three days (Thursday 6, Friday 7 and Saturday 8 July), corresponding to three chapters which are subdivided into subsections without numbering. This part is archived under the name "Papa" (Pope). Escargot investigates the time he spent in the company of his friend Brona in Valencia. These three days in July apparently coincide with Pope Benedict XVI's visit to the area to attend the "V encuentro mundial de familias" (" 5 th World Meeting of Families"). The use of dates and historical facts creates a sense of reality.

In addition it is also a word play made of the etymology of portaje. Thus, for this translation unreport is used that takes up the idea of a negative prefix unin combination with report. 
From the digital archive we can see, however, that the first visit did not take place in early July, but in mid-May, and that it consisted of not three but four days, i.e. Wednesday $17^{\text {th }}$, Thursday $18^{\text {th }}$, Friday $19^{\text {th }}$ and Saturday $20^{\text {th }}$. They were adjusted to fit the fictional calendar. In fact, it is of little importance that the actual stay in the resort happened at a certain moment of the year. The actual dates figure first, in isolation, in the file names of four short documents (of some 10-12 pages each) that were created on 13 June 2006. They are named:[10.-17_05_06 [4].doc], [20.-18_05_06 [4].doc], [30.-19_05_06 [4].doc] and [40.-20_05_06 [4].doc], i.e. 17 May 2006, 18 May 2006, and so on. In addition, there is an explicit record of the change of dates of the stay (July instead of May) in other documents created between 27 August and 1 September 2006. These notes, located in a folder at the second level [ED 03 (paris 08_06) < ED versions anteriors], received new file names in accordance with the days of the novel: [01 MD 1 julio sábado.doc], [01 MD 2 julio domingo.doc], [01 MD 3 julio lunes.doc], and [01 MD 4 julio martes.doc]. In each of the four documents we also find a footnote that is almost identical to a note that features in the first of a series of documents named [notas NOVELA] containing notes of a mainly metascriptural character. In the first notebook, dated December 2006, the entry reads as follows:

$\begin{array}{lll}\text { Novel day } & \text { Chapter } & \text { Real day } \\ \text { Sat 01/07/06 } & \text { MD } & 17 / 05 / 06 \text { (Wednesday) } \\ \text { Sun 02/07/06 } & \text { MD } & 18 / 05 / 06 \\ \text { Mon 03/07/06 } & \text { MD } & 19 / 05 / 06 \\ \text { Tue 04/07/06 } & \text { MD } & 20 / 05 / 06 \text { (Saturday) } \\ \text { Wed 05/07/06 } & \text { Modelo } & 0 \\ \text { Thu 06/07/06 } & \text { PPA } & = \\ \text { Fri 07/07/06 } & \text { PPA } & = \\ \text { Sat 08/07/06 } & \text { PPA } & =\end{array}$

The first column of this schema lists the dates of the diegesis ( 1 to 8 July). These eight days correspond to the eight chapters of the novel. The abreviations MD and PPA and the word "Modelo" denote the thematic core of the three parts: Marina d'Or (MD), Modelo prison and Pope (PPA). In the third column, the author points to which day of the real calendar (July 2006) each of the chapters and ficticious episodes is linked. The 6th, 7th and 8th July in fiction are identical $(=)$ to the real days. The chapter "Modelo" (future second part) does 
not refer to any real day (0). In other words, the first three days in July actually took taken place in May 2006.

In the same document, Juan-Cantavella mentions, also for the first time, the first three parts of his book: $01 \mathrm{MD}, 02 \mathrm{MODELO}, 03$ PAPA, which permits to affirm that he thought early on of a novel in three parts. However, this decision must have been called into question halfway into writing, since of the versions seven to eleven (that is, from 30 January to 20 April 2007) only the folders [Marina $\mathrm{d}^{\prime} \mathrm{Or}$ ] and [Papa] are preserved. The only Word document that is part of the folder [Modelo] became part of the folder [Papa] but regained autonomy from the twelfth version onwards, dated 26 May 2007, maintaining the three-fold structure almost to the end.

The fourth and last part was written quite late, that is to say, in January 2008, and only a partial sketch of it is preserved in the folder [ED 25 (04_01_08)]. The document is named [Último capitulo.doc]. In it coexist textual fragments, schematic notes which articulate the sequence - e.g. "DÓNDE: Escrito desde un tejado de esa calle de Berlín que una noche al año destruyen entre los grupos anarquistas y la policía. CUÁNDO: Escrito esa noche" ("WHERE: Written on a roof of that street in Berlin which one night per year is destroyed by groups of anarchists and the police. WHEN: Written that night"); and finally, metascriptural instructions of the type "Enlazar este último cap con las entradillas del Índice" ("Connect this last chapt to the lead-ins of the table of contents").

Juan-Cantavella told me that he had decided to add this part only when he got to the end of the relating the facts about the trip to Valencia to give the account a "novelistic" touch. On the other hand, and slightly paradoxical, he underlined the veracious character of the confrontation between police and punks described in this section, a confrontation that takes place annually in Berlin around 1 May. Furthermore, he specified for me where on the site punkjournalism.com I could find the photos of his friend Juan Ferrer that illustrate these events. This example serves to show the importance of the web page, which, in this case, offers material not included on the USB stick.

That said, I would like to emphasize that if the information displayed so far comes from an examination of the tree-structure of the textual folders, all of them are also corroborated in an implicit way 
by the more than two hundred photographs of Marina d'Or, with creation dates between 19 and 20 May and uploaded to the folder [ED fotos]. The photos of the Pope's visit, however, are all dated 9 July 2006. Thus, we see that, even without the need to access the hard disc, a digital genetic file can provide a larger amount of chronological information than we are used to finding in handwritten manuscripts. In Juan-Cantavella's, the information permits us to follow closely the process of fictionalizing reality, as we see how the author, despite his affiliation with Punk Journalism, adapted the real material to his fictional needs. So although the dossier does not contain the normal traces of writing - cancellations, additions, shifts - whose absence as I mentioned earlier would appear to make our analysis practically impossible, collating and comparing the digital documents and files gives us more than an sound basis to allow an meaningful genetic investigation. I will illustrate this with a small example.

To begin with, one ought to assume that not everything was preserved. At some point the author must have deleted some of his digital files, just as he (as he told me) had discarded paper notebooks. The absence in certain files of any time indication makes it impossible to reconstruct an exact chronology. Furthermore, the earliest surviving documents date from 13 June 2006, almost a month after the actual stay, which seems to contradict the author who declared to me me that he used to transcribe the notes taken in Marina d'Or at night.

A good example of a pre-writing stage document is the file [00.notas [4].doc] which together with the [esquema materials 4 dies. doc] presents the least advanced stage of textualization. It is nonetheless a key document in the genetic file. The file contains pretextual (lists of people, possible scenes, diagrams) and metascriptural notes. Among the second of these is an early mention of the novel's final title, El Dorado, although in the course of writing JuanCantavella thought of many alternatives as well. The notes also contain information about the possible genre of the text, which is not intended to be a new example of Gonzo Journalism, but "un experimento fallido de Periodismo Gonzo" ("a failed experiment of Gonzo Journalism"), a nuance that is further explained in the displaced prologue, "El aportaje y el Punk Journalism" ("The unreport and Punk Journalism") (Juan-Cantavella 2008, 189), to which 
raciones en el cuarto de revelado, sin cortes ni podas ni tacnas... sin correcciones.

Pero es difícil hacer esto, y al final me encontré con que estaba imponiendo una estructura básicamente literaria a lo que empezó como un reportaje de periodismo normal/enloquecido. El verdadero Periodismo Gonzo exige el talento de un gran periodista, el ojo de un fotógrafo/artista y el valor suficiente para participar en la acción. Porque el escritnr debe participar en los hechos, mientras los describe, o grabar al menos, o, cc o mínimo, tomar notas. $O$ las tres cosas. La analogía más próxima al ideal probablemente sea el productor/director de cine que se escribe sus guiones, hace el trabajo de cámara y se las arregla como sea para filmarse en acción, como protagonista o, al menos, como uno de los personajes principales.

Los medios de información impresos de Norteamérica, todavía no están preparados para una cosa así. La única revista norteamericana donde yo podía conseguir que me publicasen lo de Las Vegas

Figure 3: Clipping from Hunter S. Thompson's clippings from Robert JuanCantavella's archive.

I will return in a moment. The notes, finally, also provide JuanCantavella's objectives: "El objetivo es desviar la atención de mi verdadera investigación, que es buscar el Dorado" ("The aim is to divert the attention from my real investigation, which is search for the Dorado"); and the method that is to be followed: "Para poder investigar tranquilamente el requisito imprescindible es ocultarse entre la gente del lugar en el que se investiga, desaparecer entre la masa, convertirse en uno de ellos [comentario sobre Malinowski, la empatía, los argonautas y los diarios ... .]" ("In order to be able to calmly research the indispensable requirement is to hide among the people of the research location, disappear in the masses, turn into one of them (comment about Malinowski, empathy, the argonauts and the dairies...)]".

As with the text files, only a part of files that illustrate the documentation stage of the writing before the investigation is preserved. In general, these are documents about Marina d'Or (press notice, bills, chats, newspaper clippings, advertisements, etc.). There are also two extracts, without bibliographical reference, about Gonzo Journalism (in .jpg format). They were archived in a folder with remants [Off MD] stored in the folder [ED materiales], a folder that contains a diverse range of materials and is difficult to explore. The fragments are two quotations from Hunter S. Thompson in which he comments on his novel Fear and Loathing in Las Vegas. Although the source was not referenced, I was able to deduce it from another 
document, named [01.-intro aportaje [4].doc], with creation date 23 July 2006, where the quotations were used.

In actual fact no less than four versions exist of the document [01.-intro aportaje [4].doc] stored in as many folders at level two in the tree structure. In the first 4 versions retained from the novel, the "introducción" is an autonomous piece that functions as the prologue to the three parts of the novel that are then in existence. When the fifth version of the novel is created, this prologue lost its autonomy and became a subsection of the second part of the novel when it was integrated with the four documents created after 23 July 2006. The fourth version of the novel in progress [ED 04 (Belgrado 09_06)] bears witness to this disappearance: folder [02 Modelo] contains a detailed outline of the second part of the novel named [02 Modelo 5 julio miercoles.doc], with creation date 5 November 2006, the same date as the first version of the document saved in folder [ED 04].

ESQUEMA

1-llegada a Barcelona

2-encuentro en la puerta de la Modelo y salimos de la ciudad (escrito)

3-habla Escargot, Brona en silencio

4-episodio con los Auster (escrito)

5-Brona lee partes del aportaje MD en el ordenador

6-Brona lee el aportaje

7-Brona le cuenta a Escargot el Diario de Malinowski

8-se cuenta el tema de los mails y los sms

9-Ir a Mediamarket

X-El problema de adicción de Brona al deporte

OUTLINE

1-arrival in Barcelona

2-meeting at the door of Modelo and leaving the city (written)

3-Escargot speaking, Brona silent

4-episode with the Austers (written)

5-Brona reads parts of the unreport MD on the computer

6-Brona reads the unreport

7-Brona tells Escargot Malinowski's dairy

8-the story of the emails and SMS

9-Going to Mediamarket

X-The problem of Brona's sport addiction 
What happened next? Let us see from the protagonist's hand:

Mi querido Caracolillo, siempre tan ordenado: día1sábado.doc, estallido de la apoteosis vacacional, día2domingo.doc, ¿qué es esto?, joder, Caracolillo, otra vez haciendo periodismo de barra y dándole bola a los camareros . . . día3lunes.doc, día4martes.doc . . . Hoy es miércoles.doc, Caracolillo, día cinco, ¿qué tenemos en el menú?, ¿qué pasará hoy?, ¿ya lo tienes previsto? ... Y esto. . ¿qué es esto?

-¿Qué es qué?

-Este archivo, aportaje_Punk-Journalism.doc.

-Es el prólogo - responde Escargot -, lo escribí el viernes, cuando decidí aceptar el encargo. Pero al final no lo voy a meter.

- ¿Cómo que no lo vas a meter?

-Pues eso, que el prólogo no lo voy a incluir en el aportaje.

- ¿Por qué? No tiene mala pinta, es decir, es largo ¿no?, déjame ver . . . sí, seis páginas, seguro que sacas algo. Ay, Caracolillo, siempre con tus gilipolleces. . . aunque yo tengo algo mucho mejor, verás cuando te cuente lo que encontré allí dentro. . . Pero espera, déjame leerlo: (186)

[My beloved Caracolillo, always so organized: day1Saturday.doc, burst of the holiday climax, day2Sunday.doc, what's this?, shit, Caracolillo, again doing bar journalism and paying attention to the waiters... day3Monday.doc, day4Tuesday.doc . . . Today is Wednesday.doc, Caracolillo, day five, what's on the menu?, what will happen today?, have you already planned it? ... And that ... what's that?

-What is what?

-This archive, aportaje_Punk-Journalism.doc.

- It's the prologue - answers Escargot - I wrote it on Friday, when I decided to accept the order.

But in the end I won't put it.

- How is it that you are not going to put it? unreport.

- Well that, I'm not going to include the prologue in the

- Why? It doesn't look bad, well, it's lengthy, isn't it?, let me see. . . yes, six pages, you can certainly take something out. Oh, Caracolillo, you always with your stupid comments ... even though I have something much better, you'll see when I tell you what I found in here ... But wait, let me read it: (186)]

After the colon, we - Brona and the readers - can proceed to reading "El APORTAJE Y EL PUNK JOURNALISM" ("THE UNREPORT AND 
PUNK JOURNALISM'), the poetics of the novel, which corresponds to point 6 of the outline. Taking another look, we see that the author alludes to the second and the fourth items, which are highlighted in yellow in the archive and which correspond to the second part of the handwritten notes of the logbook transcribed in August 2006.

Curiously, if this essay now serves as an interval between the two "Película(s) hacia el sur" ("Movie[s] towards the south") that comprise the second part of the novel (the items 1-5 and 7-10 in the outline respectively), it becomes in turn a hinge for the two Gonzo unreports. The genetic documents seem to corroborate the idea put into Escargot's mouth, that is to say, that the essay was first thought of as a prologue, and then as "prólogo descartado" ("dismissed prologue"), a subtitle which figures as such in document [prologo aportaje [02].doc] of folder [ED 04], dated before the end of November. With the exception of the title, this document was almost identical to the other four, whose titles also underwent slight modification, the most significant being "EL APORTAJE Y EL pulp journalism. Prólogo descartado" ("The unreport and pulp journalism. Dismissed prologue") and the substitution of "Pulp" by "Punk" in the twenty-second version of the novel, in a document named [2.5 julio miércoles.doc], with creation date 18 December 2007. In the published novel no trace exists of this last minute change. Pulp and Punk journalism are not, however, synonyms and represent two options of writing, as Juan-Cantavella explained to me. ${ }^{6}$ This document [2.5 julio miércoles.doc] reveals, furthermore, that in December 2007 the author had not yet joined together the eight documents that correspond to the eight days of the novel, which does not happen until version twenty-four, dated two days later. Likewise, the subtitle "Tras el Punk Journalism" ("After Punk Journalism") and the generic term "Novela" ("Novel"), which figures in versions twenty-four, twenty-five and twenty-six (with creation dates between December 2007 and March 2008), are not used in the published version. Neither figure they in version twentyseven [El Dorado.27.EDITADO.doc].

If we compare the five initial versions of the prologue to the text as it was eventually published in the novel, we see that its global structure was kept quite stable, even though many passages were

6 For more information regarding the vacillations between "pulp" and “punk journalism, see my article cited before (2014: 339). 
subject to successive expansions - as happened for instance with the treatment of the invented etymology of the unreport and with the veracity pact (the understanding between writer and reader that everything in the novel is documented) of the new journalism, etc. The order in which several of these passages appeared was changed too, as was the case with comparisons between Old, New and Punk Journalism; its relationship to North American realism, to photography, and to literature as a whole. One important element that disappeared altogether was the comment that framed Hunter S. Thompson's fragment, "única persona autorizada en este particular" ("the only person authorized in this matter"); it is made more explicit because "un aportaje no es Periodismo Gonzo" ("an unreport is not Gonzo Journalism"), but "un experimento fallido de Periodismo gonzo" ("a failed experiment of Gonzo Journalism". The reason why resides in a difference in intention: "Se me ocurrió que lo que en el caso de Miedo y asco en Las Vegas: Un viaje salvaje al corazón del sueño americano había sido una desviación en la escritura o una anomalía en la percepción u otra especie de error decisivo, podría convertirse en el propósito, en el único objetivo de $E l$ Dorado: Un experimento fallido de Periodismo Gonzo" ("It came to my mind that in the case of Fear and Loathing in Las Vegas: A Savage Journey to the Heart of the American Dream it was a deviation in writing or an anomaly in perception or another type of crucial error, could turn into a purpose, into the only goal of El Dorado: a failed experiment of Gonzo Journalism").

The difference in intention affects, of course, the resources and explains why "en el caso del Punk Journalism no sólo se importan las elegantes trampas de la narración realista sino también otras menos respetables que tienen que ver con la pura fabulación, la parodia maliciosa, la mentira sincera, la especulación camicace, el despropósito gratuito, la irresponsabilidad meditada, etc. . . ." ("in the case of Punk Journalism not only the elegant traps of realist narration are imported, but also less respectable traps which have to do with pure invention, malicious parody, sincere lie, kamikaze speculations, gratuitous nonsense, meditated irresponsibility, etc. . . .) (Juan-Cantavella 2008, 189).

That said, the forty years that separate us from the Old Journalism and the digital revolution explain why the objective could no longer be "photographic". 


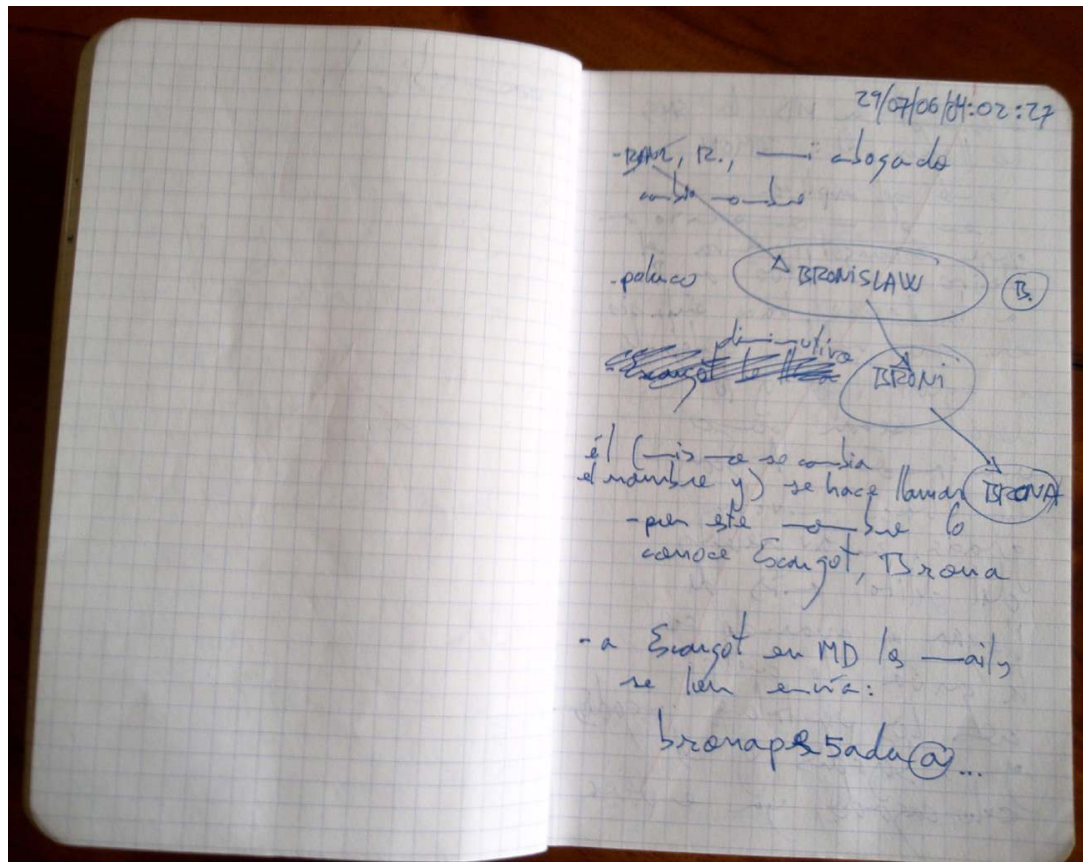

Figure 4: A page from the El Dorado notebook, (C) Robert Juan-Cantavella.

Now then, it is not explained why Hunter S. Thompson is quoted explicitly in the working papers, why even he remained somewhat in the shadow despite the fact that his work broadly conditioned the topic and the writing process of the Gonzo reports. In my opinion, the answer could be related to the importance acquired by Malinowski's field notes, which could explain why the second part of the novel does not respond to the writing norms of the two unreports. The notebook reveals that this counterpoint work by the Polish anthropologist projects itself towards the thresholds of writing and is equated to Gonzo Journalism as Juan-Cantavella practises it.

The difference that exists between the ideal conditions of "gonzo writing" and the writing of non-referential or non-documentary fiction is reflected in the difficulties that Juan-Cantavella skilfully experiences and overcomes at the moment of devising that second part of El Dorado. The conditions of the Gonzo writing are those displayed by Thompson in the following statement: "comprar un 
cuaderno gordo y registrarlo todo, tal y como viene, y luego mandar el cuaderno para que lo publicaran sin correcciones" ("buy a thick notebook and record everything, such as it comes, and then send the notebook to be published without any corrections"); JuanCantavella puts this, as far as possible, into practice in the two unreports. Whereas the writing of non-referential or non-documentary fiction has to be related to the second part of the novel, which though not pure invention does not correspond to any real day and mixes autofiction and poetics. In the novel, the poetics of Gonzo Journalism are revisited and merged with a playful rereading of Malinowski. This allows us to read El Dorado not only as a novel, but also as an example of "anthropology of the proximity", of which Marc Augé speaks in Non-Lieux: Introduction à une anthropologie de la surmodernité (1992). It is true that for this we also need to have in mind what differentiates Juan-Cantavella's research from Malinowski's anthropology, and that it is merely a poetic mise en abyme. Even if it respects the guidelines of Thompson's Gonzo Journalism, the Punk Journalism surpasses and vindicates its character of "artificio textual" ("textual artefice") (Juan-Cantavella 2008, 191).

\section{Writers face the digital challenge}

Up to this point, I have set out how the geneticist can try to take control of this new scientific object that constitutes the digital corpus. However, the exploration of a digital corpus also shows us another question mark regarding the first one set by Lebrave. That is, about how the writers appropriate the computer. In the present case, I am highlighting two aspects: one, the part of creation; the other, the part of editing; two aspects which, in a not too distant future, might allow for a reconciliation of the genetic study and edition.

Referring to the new forms of creation, the study of the genetic file, in particular of the folders [ED materiales] and [ED fotos], documents new forms of intermediality, which by far overcome traditional intertextuality and interdicursivity. In the folder [ED fotos], we find, for example, the photographs that allow us to read the humorous pages in El Dorado dedicated to the super grandmothers, Lilith, Striga and Baba Yaga, as ekphrasis of images that are 
buried in the author's archive out of respect for their personal integrity. They illuminate and render concrete what should be mentally reconstructed when reading the novel, i.e. the "agria expression" ("bitter expression"), the "ceño fruncido" ("furrowed brow"), the painted brow "a juego con el tinte de la cabellera" ("matching the hair dye"), or the "mueca despreocupada" ("carefree expression face") of the protagonists (pp. 35-36).

The [ED materiales folder] also contains links to web pages. These links corroborate what Jean-Louis Lebrave foresaw: that the creator's future paradise comes "du côté des outils de fouille de données dont nous disposons avec internet" (Lebrave 2010, 158) ("from the side of data mining tools which we have at disposal with the Internet'). And by saying this, Lebrave thought of a Flaubert of the twenty-first century searching topographical information about Palestine on Google or Google Maps. In the present case, it can be seen how Juan-Cantavella consulted various web pages to acquaint himself with a broad panoply of drugs, whose packaging, forms, colours and effects he is infusing into the novel, in no less hallucinatory scenes than those of the movie Las Vegas Parano.

If these examples allow us to examine some effects of the impact of the visual or digital culture in the act of creation, the author's web page obliges us to look to the area of the so-called narratives across Media. When presenting the genetic dossier, I have mentioned that on the back cover of the novel readers were invited to consult the author's web page, Punkjournalism.net. The website consists of six sections: "Punk Journalism. Ensayo breve", "Mai Tai. El cóctel", "Artículos de Trebor Escargot (2002-2008)", "Perfil y contacto", "El libro" and "Materiales de El dorado página por página". "Punk Journalism" comprises a digital version of the poetics of the novel from the dismissed prologue that I discussed earlier. "Mai Tai" offers the recipe of a cocktail of drugs that the protagonist savours at various moments in the account. "Artículos de Trebor Escargot" brings together some twenty articles which were published under Escargot's name in reviews and magazines, which forms another instance of the blurring of the boundary between reality and fiction, though this time it is the fiction that intervenes in the real world. This device provides depth to the novel and draws the attention to the journalistic duplicity, a feature of Punk Journalism that the book defends. "Perfil y contacto" reproduces two interviews 
with Trebor Escargot that were published previously - the first in Quimera (287, October 1987), the second on Vicente Luis Mora's blog (February 2006). The first interview also features in the novel almost in its entirety (pp. 176-180). It deals with the "honour complaint" that the Sociedad General de Autores y Editores had lodged against Escargot after he had called them a horde of "pirates" in "La horda de los gestores", an article also published in Quimera (282, May 2007). In other words, elements of the extradiegetic reality have been incorporated into the narrative work, which result in an effect of derealization and metaleptic transgression. Finally, in the section "Materiales", we see how the writer turns potential editor, not to say geneticist, of his own novel. In fact, as with the materials contained on the USB stick, we find here broad "crude or derived" materials from the novel. A headnote explains that this section "funciona como una especie de aparato virtual de notas" ("functions like a type of virtual note device"), and that the documents are indexed and linked using the page numbers in the book to which reference is made. While these materials are not needed for a reading of the novel, they open the door to the writer's studio. The reproduction of various press clippings (the originals of which were in the backpack that the author handed to me) allow us to see how the author appropriates reported speech with a view to developing a literary discourse with a "reality effect". The presence of different markers of reported speech (quotation marks, explicit references to the newspaper quoted, reporting verbs, etc.) in the novel and a list of sources included at the end of the novel prevent us to speak of "a poetics of plagiarism", but of a generalized practice of détournement as described by Guy Debord (2006).

\section{Conclusion}

First, I examined how geneticists can approach the new forms of digital writing - for example, from the examination of a digital tree-structure and the evolution of its files. Second, some specific examples were given to illustrate how a younger generation of writers appropriate digital writing on the level of creation (intermediality) and the dissemination or expansion of their work (web page). With this we have at our disposal some first data that allows for a concrete assessment of the future of genetic criticism. If the use 
of word processing becomes widespread in the creative process, it is very probable that we will lose what is beyond writing. Let us call it the non-verbal, the visible, the graphic, that is, an object which contemplates the manuscript as a "réseau de signes qui instaure une page en image" (Crasson and Hay 2013) ("network of signs which establishes a page as an image") and which justifies an alliance between genetics and semiotics. After all, any possible loss is balanced out by other techniques of semiotic character and justifies the term "design novel" which Vicente Luis Mora (2013) advocates in order to describe some creations of the Pangaea era.

\section{Bibliography}

Augé, Marc. 1992. Non-Lieux: Introduction à une anthropologie de la surmodernité. Paris: Seuil.

Crasson, Aurèle and Louis Hay. 2013. "Scripto-Graphies". In Verbal/ Non verbal. Ed. by Aurèle Crasson and Louis Hay. Special issue of Genesis, 37, 7-9.

de Biasi, Pierre-Marc. 1998. "Qu'est-ce qu'un brouillon? Le cas Flaubert". In Michel Contat and Daniel Ferrer (eds.), Pourquoi la critique génétique? Méthodes et théories. Paris: CNRS Éditions, pp. 31-60.

——. 2010. "Pour une génétique généralisée: L'approche des processus à l'âge numérique". Genesis, 30, pp. 163-75.

Debord, Guy. 2011. Génétique des textes. Paris: CNRS. Debord, Guy. 2006. "Modes d'emploi du détournement". In Oeuvres. Ed. by Jean-Louis Rançon and Alice Debord. Paris: Gallimard, pp. 221-29.

Doquet-Lacoste, Claire. 2007. “L'objet insaisissable: l'écriture sur le traitement de texte". Genesis, 27, pp. 35-44.

Ganascia, Gabriel and Jean-Louis Lebrave. 2009. "Trente ans de traitements informatiques des manuscrits de genèse". In Olga Anokhina and Sabine Pétillon (eds.), Critique génétique: concepts, méthodes, outils. Caen: IMEC, pp. 68-82.

Grésillon, Almuth. 1994. Éléments de critique génétique: Lire les manuscrits modernes. Paris: PUF.

Hay, Louis. 1985. “'Le texte n'existe pas'. Réflexions sur la critique génétique". Poétique, 62, pp. 147-58.

—_. 2010. “Une génétique sans rivages?”. Genesis, 31, pp. 153-55. 
Juan-Cantavella, Robert. 2008. El Dorado. Barcelona: Mondadori.

Kunz, Marco and Gómez Sonia. 2014. Nueva narrativa española. Barcelona: Linkgua.

Kirschenbaum, Matthew. 2008. Mechanism, New Media and the Forensic Imagination. Cambridge, Mass. and London: MIT Press.

Lebrave, Jean-Louis. 1994. "Hypertextes — mémoires — écritures". Genesis, 5, pp. 9-24.

—_. 2008. "De l'édition informatisée à l'édition électronique". In Aurèle Crasson (ed.), L'édition du manuscrit: De l'archive de création au scriptorium électronique. Louvain-la-Neuve: AcademiaBruylant, pp.169-87.

__ 2009. "Manuscrits de travail et linguistique de la production écrite". Modèles linguistiques, 59, pp. 13-21.

—_. 2010. “L'ordinateur, Olympe de l'écriture?". Genesis, 31, pp. 159-61.

—_ 2011. "Computer forensics: La critique génétique et l'écriture numérique". Genesis. 33, pp. 137-47.

—_. 2012. "Génétique électronique". In Bénédicte Vauthier and Gimena Gamba Corradine, (eds.) Crítica genética y edición de manuscritos hispánicos contemporáneos. Salamanca: Ediciones Universidad Salamanca, pp. 283-294.

Mora, Vicente Luis. 2013. El lectospectador. Barcelona: Seix Barral, 2013.

Ries, Thorsten. 2010. “'die geräte klüger als ihre besitzer': Philologische Durchblicke hinter die Schreibszene des Graphical User Interface". Editio, 24, pp. 149-99.

Vauthier, Bénédicte. 2014. “Tanteos, calas y pesquisas en el dossier genético digital de El Dorado de Robert Juan-Cantavella". In Marco Kunz and Sonia Gómez (eds.), Nueva narrativa española. Barcelona: Linkgua, pp. 311-45. 